\title{
Thirlwall's Law: The Case of Turkey, 1987-2011
}

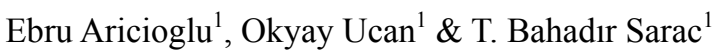 \\ ${ }^{1}$ Department of Economics, FEAS, Nigde University, Nigde University, Nigde, Turkey \\ Correspondence: Ebru Aricioglu, Department of Economics FEAS, Nigde University, Nigde, Turkey. Tel: \\ 90-388-225-4294. E-mail: ebruaricioglu@gmail.com
}

Received: August 2, 2013

Accepted: August 6, $2013 \quad$ Online Published: August 26, 2013

doi:10.5539/ijef.v5n9p59

URL: http://dx.doi.org/10.5539/ijef.v5n9p59

\begin{abstract}
This study applies Thirlwall's law to Turkish economy from 1987:Q1 to 2011:Q4 period using Autoregressive Distributed Lag (ARDL) model and Kalman Filter method. Turkish economy has balance of payments deficits for last three decades. According to Thirlwall's law this deficits constrains countries' growth rates and therefore when countries long term growth rates are analyzed the demand side of the economy and the balance of payment performance must be taken into account. The hypothesis of Thirwall's law is tested by various forms of the model. The finding implies that balance of constraint growth model is not valid for Turkey.
\end{abstract}

Keywords: balance of payments constrained growth, weak form, strong form, Kalman filter method

\section{Introduction}

Thirlwall's law or balance of payments constrained growth model provides a different viewpoint to growth theory from orthodox economic (classical and neoclassical) approach. The orthodox theory, as Say Law emphasizes, is a supply determined model and the balance of payments is self equilibrating, and growth is determined by the growth of factor inputs and technical progress. According to Thirlwall (1979), this approach cannot explain why growth rates are different between countries and he stressed that as distinct from orthodox theory, countries growth of income are demand-determined and specially in a global world (or in an open economy) demand is constrained by balance of payments. Therefore it is impossible to understand differences in the long-run economic growth of countries without reference to the balance of payments (McCombie\&Thirlwall, 2004).

The aim of the paper is to investigate the empirical validity of Thirlwall's law for Turkish economy 1987:Q1 to 2011:Q4 period. The paper follows several studies which use ARDL model, but on the other hand our paper is different from previous studies, as we add Kalman filter method together with ARDL model. The paper consists of six sections. In first section we will analyze original model (Thirlwall, 1979; Thirlwall \& Hussian, 1982). Moreover in this section the criticisms and contributions to the model (Elliott \& Rhodd, 1999; Moreno-Brid. 2003; McGregor \& Swales, 1985) are included. In the second section previous studies will be summarized in terms of findings and method. Next, Thirlwall's law will be tested in the context of Turkey. Section 4 gives empirical results and finally conclusion.

\section{Theoretical Model}

In this model beginning proposition is that no country can grow faster than that rate consistent with balance of payments equilibrium on current account unless it can finance ever-growing deficits, which in general it cannot (Thirwall, 2011). In this direction in his pioneering paper/study Thirlwall (1979) analyzed growth experience of major developed countries and he showed that the growth rates of these countries approximates to the rate of growth of exports divided by the income elasticity of demand for imports. This result is known as Thirlwall's law in the literature.

The simplest way to model growth within a balance of payments constrained framework, to start with the balance of payments equilibrium condition; specify export and import demand functions, since import growth is a function of domestic income growth, solve the model for the growth rate consistent with long-run balance of payments equilibrium (Thirlwall, 2011)

Current account equilibrium is given by: 


$$
P_{d} X=P_{f} M E
$$

where $\mathrm{X}$ is exports, $M$ is imports, $P_{d}$ is the domestic price of exports; $P_{f}$ is the foreign price of imports, $E$ is the exchange rate measured as the domestic price of foreign currency.

Export and import demand functions are specified as multiplicative with constant elasticities giving:

$$
\begin{aligned}
& X=a\left(P_{d} / P_{f} E\right)^{\eta} Z^{\varepsilon} \eta<0, \varepsilon>0 \\
& M=b\left(P_{f} E / P_{d}\right)^{\psi} Y^{\pi} \psi<0, \pi>0
\end{aligned}
$$

where $\eta$ is the price elasticity of demand for exports, $\varepsilon$ is the income elasticity of demand for exports; $\psi$ is the price elasticity of demand for imports; $\pi$ is the income elasticity of demand for imports, $Z$ is the level of world income and $\mathrm{Y}$ is domestic income.

Taking logarithms of equations (2) and (3), differentiating with respect to time, substituting the growth of exports and imports into equation (1) in growth rate form, and solving for the growth of income, gives:

$$
y_{B}=\left[(1+\eta+\psi)\left(p_{d}-p_{f}-e\right)+\varepsilon(z)\right] / \pi
$$

where the lower-case letters represent rates of growth of the variables (Thirlwall, 2011:16).

If relative prices in international trade or real exchange rates are constant, equation (4) reduces to:

$$
y_{B}^{*}=\varepsilon(z) / \pi
$$

Since we don't have information on $\varepsilon(\mathrm{z})$ for all countries it can be assumed that $(\mathrm{z})=\mathrm{x}$,

$$
y_{B}^{* *}=x / \pi
$$

Perraton (2003) termed equation (5) strong form of the Thirlwall's law and equation (6) weak form of the law. Because if the parameter $\varepsilon$ has not been estimated, using equation (6), then export growth (x) must include the effect of relative price changes as well as the effect of world income growth which weakens somewhat the argument that the balance of payments is always brought into equilibrium by domestic income changes. The model is best tested, therefore, using the "strong" version if robust estimates can be made of $\varepsilon$ (Thirlwall, 2011)

According to this schema differences in growth rates are predominantly caused by international differences in the values of $\varepsilon$ and $\pi$ which reflect all aspects of non-price competitiveness- factors which change relatively slowly over time (Arestis\&McCombie, 2006). Non-price competitiveness reflects such supply-side characteristics as quality, after-sales service, the effectiveness of distribution networks, and so on. Consequently, while this approach stresses the importance of the growth of demand for exports in the growth process, this is a function of what may be termed a country's supply characteristics (McCombie, 1997).

Thirlwall's law or balance of payments constrained growth model has been extended and modified in the course of time. Specifically, Thirlwall and Hussian (1982) taking consideration of developing countries growth experience extended the model to include capital inflows. Therefore, capital flows included model can be regarded as developing country version of the Thirlwall's law.

By definition, including capital flows the overall balance of payment can be written like as following:

$$
P_{d} X+C=P_{f} M E
$$

which is a simple extension of equation (1) where $C>0$ represents positive capital inflows, $C>0$ representes capital outflows. Taking rates of change of the variables in equation (7), and using expressions for the rate of growth of exports and imports from equations (2) and (3), gives the growth rate consistent with overall balance of payments (ob) of:

$$
y_{o b}=\left[(1+\theta \eta+\psi)\left(p_{d}-p_{f}-e\right)+\theta \varepsilon(z)+(1-\theta)\left(c-p_{d}\right)\right] / \pi
$$

where $\theta$ is the share of export receipts in total receipts to pay the import bill; $\mathrm{c}$ is the growth of nominal capital 
inflows, so that $\left(\mathrm{c}-p_{d}\right)$ is the growth of real capital inflows (Thirlwall, 2011).

Again if we make the assumption that relative prices measured in a common currency remain unchanged over the long term equation (8) reduces to:

$$
y_{o b}^{*}=\left[\theta x+(1-\theta)\left(c-p_{d}\right)\right] / \pi
$$

In other words, the growth rate consistent with the overall balance of payments is the weighted sum of the growth of exports and real capital flows divided by income elasticity of demand for imports. If there were no capital flows [i.e. $\theta=0$ and $\left(c-p_{d}\right)=0$ ], then equation (9) would collapse to the simple rule in equation (6) that $y=x / \pi$ (Thirlwall, 2011).

Later, in addition to capital flows Elliott and Rhodd (1999) included debt and debt service components. Moreno-Brid (2003) also included interest payments on debt to the model. Even if the growth of interest payments is quite high and debt service ratio is also high, it stil makes little difference to the predicted growth rate. In other words export growth dominates (Thirwall, 2011).

Thirlwall law's empirical validation is sought by different econometric tests. First of all, model is tested using Spearman's rank correlation by Thirlwall (1979). According to McGregor and Swales (1985), the use of this nonparametric test is very weak and it would seem more reasonable to test Equation (6) directly using regression analysis. In the light of criticims made by McGregor and Swales (1985) the law is usually tested as follows: firstly trade functions are estimated in order to obtain the corresponding elasticities; secondly, the income growth rate consistent with external equilibrium is calculated as Equation (6); and, finally, a regression is made of the growth rate of income consistent with external equilibrium on the actual growth rate (Alonso, 1999).

McGregor and Swales (1985), argue that for these regressions to be consistent with the theory, the constant term should be zero and the regression coefficient unity (Thirwall, 1986). The problem with this test, however, is that it requires a full set of countries for the whole world in which deficits and surpluses cancel out. If the only countries taken are predomiantly deficit countries, the constant would exceed zero, and the slope is likely to differ from unity, and the hypothesis that growth is the balance of payments constrained would be rejected because of inappropriate sample choice (Thirlwall, 2011).

The second parametric test suggested by McCombie (1989), is to take each country separately and to estimate the income elasticity of demand for imports $\left(\pi^{*}\right)$ that would equate actual growth rate and balance of payments constrained growth rate, and to compare this estimate $\left(\pi^{*}\right)$ with the estimated $\pi$ from the time-series regression analysis for the country under consideration. If $\pi^{*}$ does not differ significantly from $\pi$, then actual growth rate and balance of payments constrained growth rate will not differ significantly either (McCombie \& Thirlwall, 2004).

Thirlwall (2011) emphasizes that the econometric methods which are used in studies have become much more sophisticated and the tests of the model have become more rigorous. But the most notable shift of all has been towards the use of cointegration techniques to establish long-run relationships between levels of variables. Alonso (1999), which is one of the earliest works in this direction, used cointegration techniques for an individual country to estimate $\pi^{*}$ taking levels of variables in the export and import demand functions. The level of income consistent with balance of payments equilibrium is then calculated and the actual growth of income is regressed on this "equilibrium" level of income. If the constant is not significantly different from zero and the regression coefficient is not significantly different from unity, this indicates parallel evolution of two series (Thirlwall, 2011).

\section{Literature Review}

Thirlwall's law is tested for both a single country such as; Atesoglu (1993), Hieke (1997), León-Ledesma (1999), YongbokJeon (2009) and country groups Thirlwall and Hussain (1982), Andersen (1993), Perraton (2003) and Bagnai (2010). 
Table 1. Summary of recent literature review for Thirlwall's Law

\begin{tabular}{|c|c|c|c|}
\hline Author(s) & Countries and Period & Method & Result \\
\hline $\begin{array}{l}\text { Thirlwall and } \\
\text { Hussain (1982) }\end{array}$ & $\begin{array}{l}20 \text { Developing } \\
\text { Countries } \\
\text { (1950s to } 1970 \mathrm{~s})\end{array}$ & OLS & $\begin{array}{l}\text { Capital inflows have enabled to countries to grow slightly faster than } \\
\text { Thirlwall's expression. }\end{array}$ \\
\hline $\begin{array}{l}\text { Bairam and } \\
\text { Dempster } \\
(1991)\end{array}$ & $\begin{array}{l}11 \text { Asian Countries } \\
(1965-85)\end{array}$ & OLS & $\begin{array}{l}\text { When India and Japan are excluded form sample, the economic } \\
\text { growth is determined by Thirwall's law. }\end{array}$ \\
\hline $\begin{array}{l}\text { Atesoglu } \\
(1993)\end{array}$ & $\begin{array}{c}\text { USA } \\
(1955-70,1975-90)\end{array}$ & $\begin{array}{l}\text { OLS, two stage least } \\
\text { squares method }\end{array}$ & $\begin{array}{l}\text { Thirlwall's law can explain a satisfactory account of the variations } \\
\text { in long-term economic growth of USA economy. }\end{array}$ \\
\hline $\begin{array}{l}\text { Atesoglu } \\
(1993-94)\end{array}$ & $\begin{array}{c}\text { Canada } \\
(1961-76,1977-91)\end{array}$ & OLS & $\begin{array}{l}\text { The growth in exports has been a significant and important source of } \\
\text { Canadian economic growth but capital inflows don't appear to play } \\
\text { an important role in the economic growth. }\end{array}$ \\
\hline $\begin{array}{l}\text { Andersen } \\
(1993)\end{array}$ & 16 industrial countries & $\begin{array}{l}\text { Engle Granger } \\
\text { co-integration anlaysis }\end{array}$ & $\begin{array}{l}\text { There is a close relationship between the actual growth rate and the } \\
\text { balance of payments equilibrium growth rate in the long run and } \\
\text { even a 1:1 ratio is only obtained when Japan is excluded. }\end{array}$ \\
\hline $\begin{array}{l}\text { Hieke } \\
(1997)\end{array}$ & $\begin{array}{c}\text { USA } \\
(1950-1990) \text { quarterly } \\
\text { data } \\
\end{array}$ & $\begin{array}{l}\text { Co-integration } \\
\text { anlaysis and OLS }\end{array}$ & $\begin{array}{c}\text { According to the paper the post-World War II period U.S. economy } \\
\text { supports Thirlwall's law when the data are subdivided into the } \\
\text { periods } 1950-66 \text { and 1967-90. }\end{array}$ \\
\hline $\begin{array}{l}\text { León-Ledesma } \\
\text { (1999) }\end{array}$ & $\begin{array}{c}\text { Spain } \\
(1965-1993)\end{array}$ & $\begin{array}{l}\text { Two Stage Least } \\
\text { Squares }\end{array}$ & $\begin{array}{l}\text { Spanish economy's growth rate has been very close to the estimated } \\
\text { balance-of-payments equilibrium growth rate. }\end{array}$ \\
\hline $\begin{array}{l}\text { Elliott and } \\
\text { Rhodd (1999) }\end{array}$ & $\begin{array}{c}20 \text { Developing } \\
\text { Countries (1950s to } \\
1970 \mathrm{~s})\end{array}$ & OLS & $\begin{array}{l}\text { When debt service is included, the balance of payments constrained } \\
\text { model can predict better growth rate for } 13 \text { of the } 20 \text { countries. }\end{array}$ \\
\hline $\begin{array}{l}\text { López and } \\
\text { Cruz } \\
(2000)\end{array}$ & $\begin{array}{l}\text { 4 Latin America } \\
\text { Countries } \\
(1965-1996) \\
\end{array}$ & $\begin{array}{l}\text { Johansen } \\
\text { cointegration test and } \\
\text { VAR Analysis }\end{array}$ & $\begin{array}{l}\text { Thirlwall's law is relevant for these countries in that output growth } \\
\text { closely tracks export growth in the long run and moreover, higher } \\
\text { exports tend to cause higher output. }\end{array}$ \\
\hline $\begin{array}{l}\text { Moreno-Brid } \\
\text { and Pérez } \\
\text { (1999) }\end{array}$ & $\begin{array}{l}5 \text { Central American } \\
\text { countries } \\
(1950-1996)\end{array}$ & $\begin{array}{l}\text { Johansen } \\
\text { cointegration test }\end{array}$ & $\begin{array}{l}\text { The balance of payments constrained growth model holds for Costa } \\
\text { Rica, Guatemala and Nicaragua, but for El Salvador and Honduras } \\
\text { the balance of payments constrained growth rate is below than the } \\
\text { actual rate. }\end{array}$ \\
\hline $\begin{array}{l}\text { Alonso } \\
(1999)\end{array}$ & $\begin{array}{c}\text { Spain } \\
(1960-1994)\end{array}$ & $\begin{array}{l}\text { Johansen } \\
\text { cointegration test and } \\
\text { VAR Analysis }\end{array}$ & $\begin{array}{l}\text { The results confirm the existance of the external restriction in } \\
\text { Spanish case furthermore, prices play a minor role in external } \\
\text { adjustment. }\end{array}$ \\
\hline $\begin{array}{l}\text { Perraton and } \\
\text { Turner } \\
\text { (1999) }\end{array}$ & $\begin{array}{l}15 \text { industrial countries } \\
(1957-1995)\end{array}$ & SURE Technique & $\begin{array}{l}\text { When the observations are weighted according to the relative shares } \\
\text { in total GDP then there is a strong relationship between the } \\
\text { predictions of Thirlwall's law and actual growth rates. }\end{array}$ \\
\hline $\begin{array}{l}\text { Perraton } \\
(2003)\end{array}$ & $\begin{array}{l}51 \text { developing } \\
\text { countries } \\
(1973-95)\end{array}$ & $\begin{array}{l}\text { Error correction } \\
\text { technique }\end{array}$ & $\begin{array}{l}\text { For } 27 \text { countries the balance of payments constraint model countries } \\
\text { is a good predictor of actual growth performance, particularly when } \\
\text { the effect of terms of trade changes on import capacity are allowed } \\
\text { for. }\end{array}$ \\
\hline $\begin{array}{l}\text { Kvedaras } \\
(2005)\end{array}$ & $\begin{array}{l}\text { 10 CEE countries } \\
\text { (1995-2004) } \\
\text { quarterly data }\end{array}$ & $\begin{array}{l}\text { Conditional Error } \\
\text { Correction Model }\end{array}$ & $\begin{array}{c}\text { The balance of payments constraint model captures well the disparity } \\
\text { of growth rates of the income in } 8 \text { countries except Bulgaria and } \\
\text { Hungary. }\end{array}$ \\
\hline $\begin{array}{l}\text { Pacheco-López } \\
\text { and } \\
\text { Thirlwall(2006) }\end{array}$ & $\begin{array}{l}17 \text { Latin American } \\
\text { countries }(1977-2002)\end{array}$ & $\begin{array}{l}\text { McCombie (1989) test } \\
\text { and rolling regression } \\
\text { analyses }\end{array}$ & $\begin{array}{l}\text { The balance of payments equilibrium growth rate is a good predictor } \\
\text { of the growth performance in } 9 \text { of } 17 \text { countries. }\end{array}$ \\
\hline $\begin{array}{l}\text { Jeon } \\
(2009)\end{array}$ & $\begin{array}{c}\text { China } \\
(1979-2002)\end{array}$ & $\begin{array}{l}\text { ARDL-UECM and } \\
\text { bounds testing }\end{array}$ & $\begin{array}{l}\text { Thirlwall's law holds in China and there is a demand-oriented } \\
\text { economic growth inChina. }\end{array}$ \\
\hline $\begin{array}{l}\text { Gouvea and } \\
\text { Lima }(2010)\end{array}$ & $\begin{array}{l}\text { A sample of Latin } \\
\text { American and Asian } \\
\text { countries }\end{array}$ & $\begin{array}{l}\text { Johansen } \\
\text { cointegration analysis } \\
\quad \text { and } \\
\text { vector-error-correction } \\
\end{array}$ & $\begin{array}{l}\text { The original version of Thirlwall's law was hold for all sample } \\
\text { countries except South Korea, and the multisectoral Thirlwall's law } \\
\text { version was found to hold for all of them. }\end{array}$ \\
\hline $\begin{array}{l}\text { Felipe et. Al } \\
\quad(2010)\end{array}$ & $\begin{array}{l}\text { Pakistan } \\
(1980-2007)\end{array}$ & ARDL model & $\begin{array}{l}\text { According to the findings Pakistan's actual growth is above } \\
\text { itsbalance-of-payments constrained growth rate and the difference } \\
\text { was covered by net inward capital flows. }\end{array}$ \\
\hline $\begin{array}{l}\text { Bagnai } \\
(2010)\end{array}$ & $\begin{array}{c}22 \text { OECD } \\
\text { Countries (1960-2006) }\end{array}$ & $\begin{array}{l}\text { Engle-Granger } \\
\text { cointegration test and } \\
\text { OLS }\end{array}$ & $\begin{array}{l}\text { There is cointegration in } 16 \text { out of } 22 \text { countries. The findings support } \\
\text { Thirlwall's law only in the second half of the sample. }\end{array}$ \\
\hline $\begin{array}{l}\text { Samimi et al. } \\
(2011)\end{array}$ & $\begin{array}{c}\text { Iran } \\
(1951-2007) \\
\end{array}$ & $\begin{array}{l}\text { ARDL Bounds } \\
\text { Testing }\end{array}$ & $\begin{array}{l}\text { Empirical results show that the Thirlwall's law has been rejected in } \\
\text { Iran. }\end{array}$ \\
\hline $\begin{array}{l}\text { Grullón } \\
(2011)\end{array}$ & $\begin{array}{l}\text { Dominican Republic } \\
\quad(1960-84 \text { and } \\
1985-2005)\end{array}$ & $\begin{array}{l}\text { ECM-based bounds } \\
\text { testing }\end{array}$ & $\begin{array}{l}\text { According to the findings, throughout the inward-oriented } \\
\text { industrialization the balance of payments constrained growth rate of } \\
\text { income exceed that outward-directed industrialization. This is } \\
\text { determined by import-export income demand elasticity differentials. }\end{array}$ \\
\hline
\end{tabular}

\section{Data and Empirical Results}

The sample period covers quarterly data from 1987:1 to 2011:4 to test the weak and the strong form of Thirlwall's Law. The raw data have been collected from International Financial Statistics (IMF-IFS). Turkey's 
export volume index, import volume index, export price index and import price index, real GDP index, terms of trade and world's real GDP index and export price index variables are used.

First of all, following export and import demand functions are created in Model (1) and Model (2) respectively (Houthakker\& Magee, 1969: 112).

$$
\begin{gathered}
M_{t}=\beta_{0}+\beta_{1} Y_{t}+\beta_{2} t t_{t}+\varepsilon_{1 t} \\
X_{t}=\alpha_{0}+\alpha_{1} Z_{t}+\alpha_{2} P_{t}+\varepsilon_{2 t}
\end{gathered}
$$

$\boldsymbol{\beta}_{\boldsymbol{0}}$ and $\boldsymbol{\alpha}_{0}$ are the constant terms; $\boldsymbol{\beta}_{1}, \boldsymbol{\beta}_{2}, \boldsymbol{\alpha}_{1}, \boldsymbol{\alpha}_{2}$ are the slope terms; $\boldsymbol{\varepsilon}_{1 t}, \boldsymbol{\varepsilon}_{2 t}$ are the error terms; $m_{t}$ is the real import volume (LIMSA); $\boldsymbol{Y}_{\boldsymbol{t}}$ real GDP (LGDPSA), $\boldsymbol{t}_{\boldsymbol{t}}$ is the terms of trade (LTTSA), $\boldsymbol{X}_{\boldsymbol{t}}$ is the real export volume (LEXSA); $\boldsymbol{Z}_{t}$ is the world's real GDP (LWGDPSA) and $P_{t}$ is the rate of Turkey's export price index over worlds export price index (LPTSA).

The raw data are taken into natural logarithm and seasonally adjusted via Tramo-Seats method. Lee - Strazicich (2003) unit root test is used to examine whether the variables are stationary or not. Test results are given in Table 1.

Table 2. Lee-Strazicichunit root results

\begin{tabular}{cccc}
\hline \multirow{2}{*}{ Series } & \multirow{2}{*}{ (t-statistics) Values } & \multicolumn{2}{c}{ Structural Breaks } \\
\cline { 3 - 4 }$($ LNIMSA) & $-5,21(1)$ & $1995: 4$ & 2nd Break \\
\hline (LNGDPSA) & $-7,45(3)^{*}$ & $1989: 4$ & $2003: 2$ \\
& $-5,33(7)$ & $2000: 4$ & $1999: 2$ \\
(LNTTSA) & $-9,49(0)^{*}$ & $1993: 2$ & $2007: 4$ \\
& $-5,44(3)$ & $1990: 3$ & $2008: 1$ \\
$($ LNEXSA) & $-7,27(3)^{*}$ & $1989: 3$ & $2000: 4$ \\
& $-4,37(0)$ & $2000: 1$ & $1991: 1$ \\
(LNWGDPSA) & $-13,94(0)^{*}$ & $1997: 2$ & $2006: 4$ \\
& $-4,66(3)^{*}$ & $1991: 4$ & $1999: 1$ \\
(LNPTSA) & $-7,47(0)^{*}$ & $1990: 4$ & $2005: 3$ \\
& $-6,07(3)$ & $2001: 1$ & $2008: 2$ \\
\hline
\end{tabular}

1) Lag lengths are in paranthesis. There is no autocorellation for these lags.

2) Critical values for Lee\&Strazicich test are taken from Lee and Strazicich $(2003,1084)$, i.e they are $-5.59,-5.74,-5.71$.

3) $\left({ }^{*}\right)$ indicates the results after first difference.

As to Table 1 , it is identified that LPSA is I(0) and other variables are I(1). Therefore, we use ARDL model to get the long run relationship. So we get the following equations:

$$
\begin{aligned}
& \Delta \text { LNIMSA }_{t}=\beta_{0}+\beta_{1} d 1+\beta_{2} d 2+\beta_{3} d 3+\beta_{4} d 4+\sum_{i=1}^{m} \beta_{5 i} \Delta \text { LNIMSA }_{t-i}+\sum_{i=0}^{m} \beta_{6 i} \Delta \text { LNGDPSA }_{t-i}+\sum_{i=0}^{m} \beta_{7 i} \text { LNNTTSA }_{t-i}+(12) \\
& \beta_{8} \text { LNIMSA }_{t-1}+\beta_{9} \text { LNGDPSA }_{t-1}+\beta_{10} \text { LNTTSA }_{t-1}+\varepsilon_{t 1} \\
& \Delta \text { LNEXSA }_{t}=\alpha_{0}+\alpha_{1} d 1+\alpha_{2} d 2+\alpha_{3} d 3+\alpha_{4} d 4+\sum_{i=1}^{m} \alpha_{5 i} \Delta L N E X S A_{t-i}+\sum_{i=0}^{m} \alpha_{6 i} \Delta \text { LNWGDPSA }_{t-i}+\sum_{i=0}^{m} \alpha_{7 i} \text { LLNPTSA }_{t-i}+(13) \\
& \alpha_{8} \text { LNEXSA }_{t-1}+\alpha_{9} \text { LNWGDSA }_{t-1}+\alpha_{10} \text { LNPTSA }_{t-1}+\varepsilon_{t 2}
\end{aligned}
$$

Here crisis dummies are d1, d2, d3 and d4 are for the years 1989, 1994, 2001 and 2008 respectively. To establish the cointegration relation we have $\boldsymbol{H}_{0}: \boldsymbol{\beta}_{8}=\boldsymbol{\beta}_{9}=\boldsymbol{\beta}_{10}=0$ and $\boldsymbol{H}_{0}: \boldsymbol{\alpha}_{8}=\boldsymbol{\alpha}_{9}=\boldsymbol{\alpha}_{10}=0$ for Model (3) and Model (4) respectively. Calculated F -statistics is compared with the critical values in the Pesaran (et.al.,) (2001). If the calculated F-statistics is bigger than the upper bound value, it will be determined to have a long run relationship, i.ecointegration. Prior to determining cointegration for the equations lag lengths are found by Schwarz Information Criteria. These results are given in Table 2. 
Table 3. Determining lag lengths

\begin{tabular}{ccccc}
\hline 0 & $\begin{array}{c}\text { Model 3 } \\
\text { (SIC) }\end{array}$ & $\begin{array}{c}\text { Model 3 } \\
(\mathrm{BG})\end{array}$ & $\begin{array}{c}\text { Model 4 } \\
(\text { SIC) }\end{array}$ & $\begin{array}{c}\text { Model 4 } \\
(\mathrm{BG})\end{array}$ \\
\hline 1 & $-2,45^{*}$ & $1,61(0,2045)$ & $-3,14^{*}$ & $3,01(0,0546)$ \\
2 & $-2,35$ & $0,02(0,9746)$ & $-3,12$ & $0,54(0,5836)$ \\
3 & -2.24 & $0,35(0,7005)$ & $-3,04$ & $0,53(0,5871)$ \\
\hline
\end{tabular}

1) $\mathrm{m}$, SIC, BG show lag lengths, Schwarz Information Criteria value, Breusch-Godfrey autocorrelation test F value, respectively. Probability values are in parenthesis.

2) There is no autocorrelation at the $5 \%$ significance level.

3) ${ }^{*}$ shows the fitting lag length.

Lag length is 1(one) for Model (3) and 1(one) for Model (4). As to results in Table 3, since calculated F statistics for Model 3 and Model 4 are bigger than the upper bound critical values there exist at least one long run relation between the variables in Model 3 and Model 4.

Table 4.Cointegrationresults

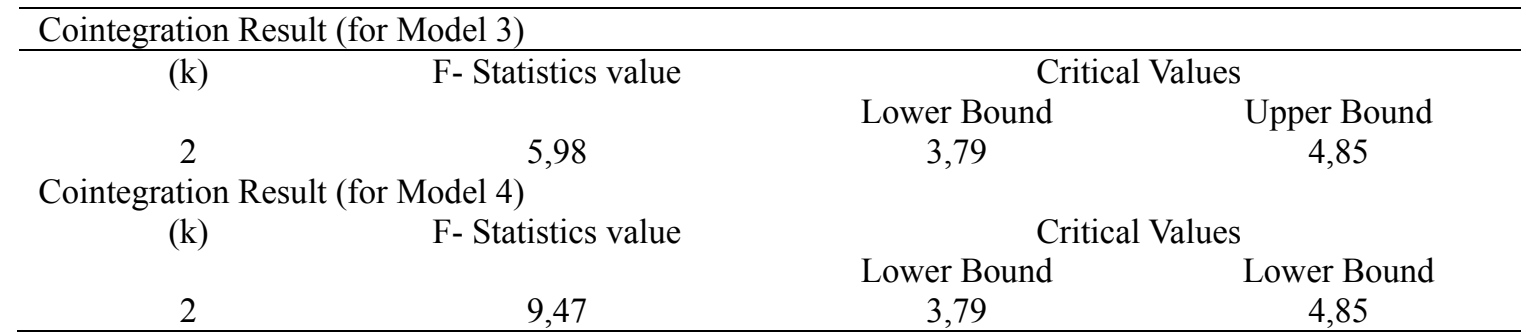

1) Critical values at the $5 \%$ significance level are taken from Pesaran, Shin and Smith (2001, 300 (Table CI (iii)).

2) (k);indicates the number of independent variables in the Model (3) and Model (4).

Because of the existence of the cointegration relation, there will be no spurious regression. Thus, the variables at the level in the Model 1 and Model 2 are used to observe $\boldsymbol{\beta}_{1}$ and $\boldsymbol{\alpha}_{\boldsymbol{1}}$ via Kalman Filter method for each models. The results are given in the Graph 1 and Graph 2.

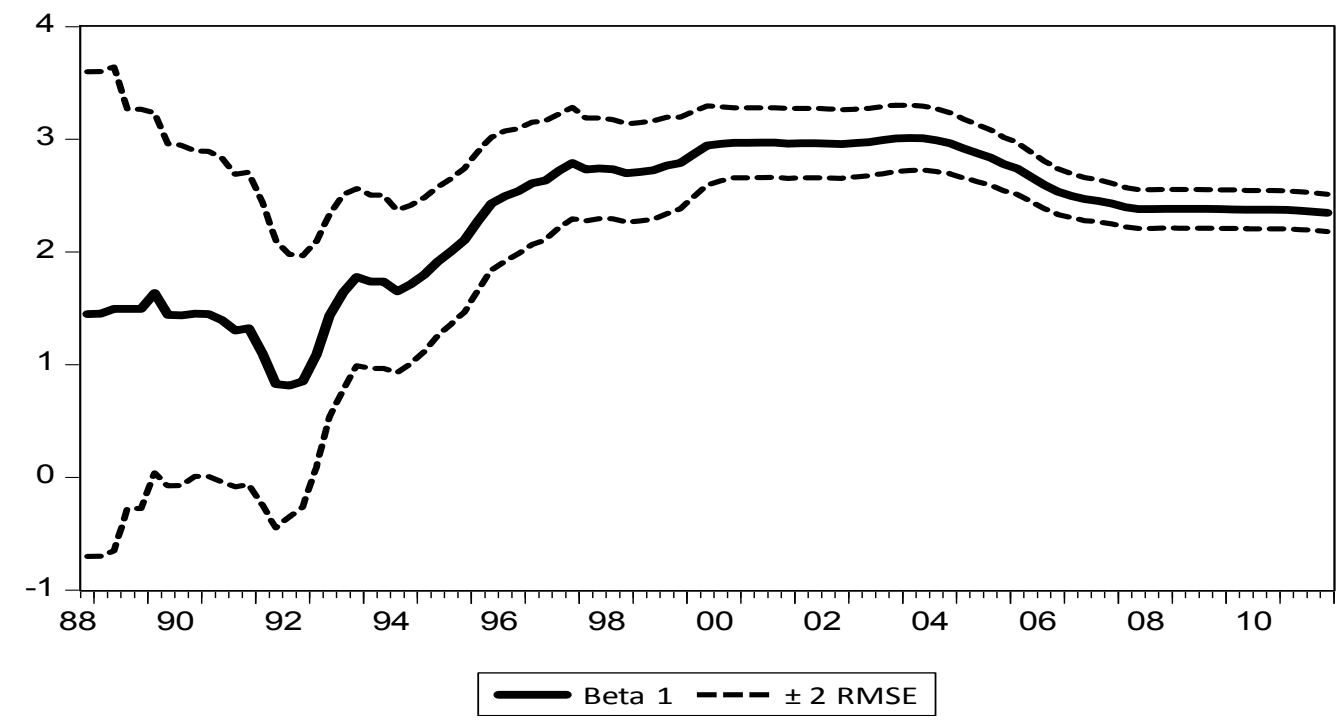

Figure 1. Kalmanfilter result (Model 1) 


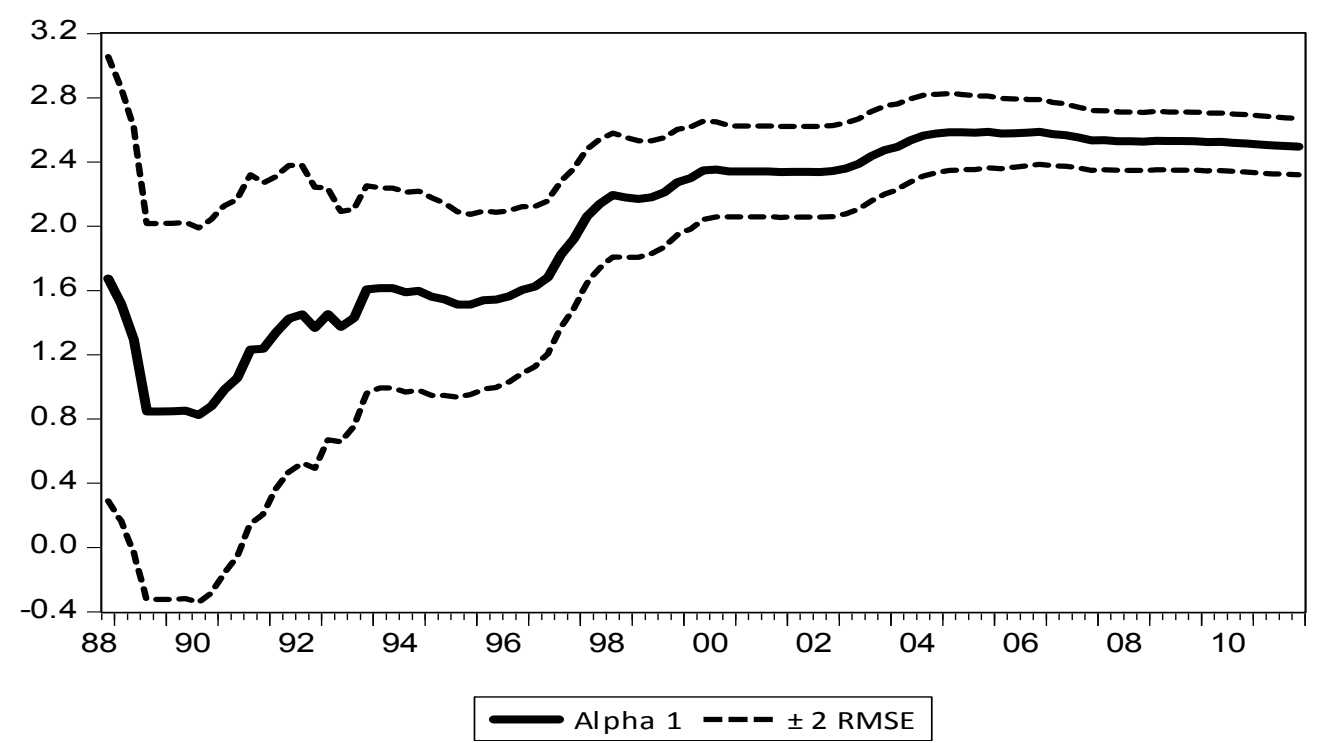

Figure 2. Kalmanfilter result (Model 2)

After getting $\beta_{1}$ and $\alpha_{1}$ coefficients via Kalman Filter method, following Perraton (2003), to test the weak form of Thirlwall Law Model (5) is created.

$$
\Delta G_{t}=\alpha_{0}+\alpha_{1} \Delta A_{t}+\varepsilon_{t}
$$

In the Model (5), $\boldsymbol{\alpha}_{0}$ is the constant term, $\boldsymbol{\alpha}_{1}$ is the slope coefficient, $\Delta G_{t}$ is the predicted growth rate, $\Delta A_{t}$ is the nominal growth rate and $\varepsilon_{t}$ is the error term. $\Delta G_{t}$ is calculated as dividing the real export growth rate by income elasticity of import $\left(\beta_{1}\right)$.

Then, data belongs to $\Delta G_{t}$ variable is examined for the unit root via Lee -Strazicich ( 2003) unit root test. The result is given in Table(4).

Table 5. Lee-Strazicichunit root test result

\begin{tabular}{cccc}
\hline \multirow{2}{*}{ Series } & \multirow{2}{*}{ (t-statistics) Values } & \multicolumn{2}{c}{ Structural Breaks } \\
\cline { 3 - 4 } & & 1st Break & 2nd Break \\
\hline$\Delta G_{t}$ & $-9,78(8)$ & $1991: 3$ & $1998: 4$ \\
\hline
\end{tabular}

1) Lag lengths are in paranthesis. There is no autocorellation for these lags.

2) Critical values for Lee\&Strazicich test are taken from Lee and Strazicich $(2003,1084)$,i.e they are $-5.59,-5.74,-5.71$.

3) $\left({ }^{*}\right)$ indicates the results after first difference.

Since $\Delta G_{t}$ is stationary, Model (5) is estimated by OLS and $\boldsymbol{\alpha}_{0}=0, \boldsymbol{\alpha}_{I}=1$ hypothesis is tested via Wald Test. As to results in Table (5), null hypothesis is rejected at the $5 \%$ significance level. 
Table 6. Test results of weak form of Thirlwall Law

\begin{tabular}{ccc}
\hline Variables & Coefficients & Probability Values \\
\hline Constant term & 0,006 & $0,006^{*}$ \\
$\Delta A_{t}$ & 0,194 & $0,033^{*}$ \\
$\operatorname{AR}(1)$ & $-0,280$ & $0,006^{*}$
\end{tabular}

$R^{2}=0,14, \quad$ Breusch-Godfrey autocorrelation $\quad \mathrm{F}$ statistics value $=0,91(0,405)$

Wald Test $F$ statistics value $=40,07(0,000)$

1) Probability values are in parenthesis.

2) ${ }^{*}$ indicates the variables that is significant at the $5 \%$ significance level.

So it is concluded that weak form of Thirlwall Law is not valid for Turkey. To test the strong form of Thirlwall Law Model (5) is created.

$$
\Delta P_{t}=\alpha_{0}+\alpha_{1} \Delta A_{t}+\varepsilon_{t}
$$

In the Model (6), $\boldsymbol{\alpha}_{0}$ is the constant term, $\boldsymbol{\alpha}_{1}$ is the slope coefficient, $\Delta P_{t}$ is the predicted growth rate, $\Delta A_{t}$ is the nominal growth rate and $\varepsilon_{t}$ is the error term. $\Delta P_{t}$ is calculated as dividing income elasticity of export $\left(\alpha_{1}\right)$ multiplying with world's real growth rate by income elasticity of import $\left(\beta_{1}\right)$.

Then, data belongs to $\Delta P_{t}$ variable is examined for the unit root via Lee -Strazicich (2003) unit root test. The result is given in Table (6).

Table 7. Lee-Strazicichunit root test result

\begin{tabular}{cccc}
\hline \multirow{2}{*}{ Series } & \multirow{2}{*}{ (t-statistics) Values } & \multicolumn{2}{c}{ Structural Breaks } \\
\cline { 3 - 4 } & & 1st Break & 2nd Break \\
\hline$\Delta P_{t}$ & $-7,95(7)$ & $2007: 2$ & $2008: 4$ \\
\hline
\end{tabular}

1) Lag lengths are in paranthesis. There is no autocorellation for these lags.

2) Critical values for Lee\&Strazicich test are taken from Lee and Strazicich $(2003,1084)$,i.e they are $-5.59,-5.74,-5.71$.

3) $(*)$ indicates the results after first difference.

Table 8. Test results of strong form of Thirlwall Law

\begin{tabular}{ccc}
\hline Variables & Coefficients & Probability Values \\
\hline Constant term & 0,006 & $0,000^{*}$ \\
$\Delta A_{t}$ & 0,033 & $0,012^{*}$ \\
$\operatorname{AR}(1)$ & 0,533 & 0,000 \\
$R^{2}=0,13$, Breusch-Godfrey autocorrelation F statistics value $=1,65(0,197)$ \\
Wald Test F statistics value $=2784,86(0,000)$ \\
\hline
\end{tabular}

1) Probability values are in parenthesis.

2) ${ }^{*}$ indicates the variables that is significant at the $5 \%$ significance level.

Since $\Delta P_{t}$ is stationary, Model (6) is estimated by OLS and $\boldsymbol{\alpha}_{0}=0, \boldsymbol{\alpha}_{I}=1$ hypothesis is tested via Wald Test. As to results in Table (7), null hypothesis is rejected at the $5 \%$ significance level. Therefore, it is concluded that strong form of Thirlwall Law is not valid for Turkey.

\section{Conclusion}

Thirlwall's law or balance of payment constraint growth model is modified in the course of the time. During this time this model's empirical validation is different empirical methods. The aim of this study is to test the validity of the Thirlwall's law for Turkey, for the period 1987-2011. After analyzing original model and its modifications 
and literature review, this studies empirical analysis is divided in two paths. Firstly the weak form of the Thirlwall Law and then strong form of the Thirlwall Law is tested by Kalman filter method together with ARDL method. This method is totally different from the other studies done in the literature dealing with Thirlwall's Law. Kalman Filter approach has a key role since it gives the income elasticities of export and import for each year that we analyzed. Getting these values help us to observe the accurate testing results. As to results, it is stated that neither weak form nor strong form of the Thirlwall Law is valid for the period 1987-2011 in Turkey. For the further studies, instead of world's data different country group's data (EU countries, Asian countries and etc.) may be taken into consideration. Moreover, instead of total export and total import values, specific sector (automotive, textile and etc.) values may be taken into consideration.

\section{References}

Alonso, J. A. (1999). Growth and the external constraint: lessons from the Spanish case. Applied Economics, 31(2), 245-253. http://dx.doi.org/10.1080/00036849932447

Andersen, P. S. (1993). The 45 rule revisited. Applied Economics, 25(10), 1279-1284. http://dx.doi.org/10.1080/00036849300000093

Arestis, P., \& McCombie, J. (2006). Growth and economic development. In Thirlwall, A. P., Arestis, P., McCombie, J., \& Vickerman, R. (Eds.). Cheltenham: Edward Elgar.

Atesoglu, H. S. (1993). Balance-of payments-constrained growth: Evidence from the United States. Journal of Post Keynesian Economics, 15(4), 507-514.

Atesoglu, H. S. (1994). Exports, capital flows, relative prices, and economic growth in Canada. Journal of Post Keynesian Economics, 16(2), 289-297.

Bagnai, A. (2010). Structural changes, cointegration and the empirics of Thirlwall's law. Applied Economics, 42(10), 1315-1329. http://dx.doi.org/ 10.1080/00036840701721299

Bairam, E., \& Georgina, J. D. (1991). The Harrod foreign trade multiplier and economic growth in Asian countries. Applied Economics, 23(11), 1719-1724. http://dx.doi.org/10.1080/00036849100000066

Elliott, R. D., \& Rhodd, R. (1999). Explaining growth rate differences in highly debted countries: An extension to Thirwall and Hussainé. Applied Economics, 31(9), 1145-1148. http://dx.doi.org/10.1080/000368499323634

Felipe, J., McCombie, J., \& Naqvi, K. (2010). Is Pakistan's growth rate balance-of payments constrained? Policies and implications for development and growth. Oxford Development Studies, 38(4), 477-496. http://dx.doi.org/10.1080/13600818.2010.525351

Gouvea, R. R., \& Lima, G. T. (2010). Structural change, balance of payments constraint and economic growth: Evidence from the multi-sectoral Thirlwall's Law. Journal of Post Keynesian Economics, 33(1), 169-204. http://dx.doi.org/10.2753/PKE0160-3477330109

Grullón, S. (2011). The balance of payments constraint as an explanation of growth rate differences in the Dominican Republic. European Journal of Social Sciences, 25(3), 386-394.

Hieke, H. (1997). Balance-of-payments-constrained growth: A reconsideration of the evidence for the U.S. economy. Journal of Post Keynesian Economics, 19(3), 313-325.

Houthakker, H. S., \& Magee, P. S. (1969). Income and price elasticities in world trade. The Review of Economics and Statistics, 51(2), 111-125. http://dx.doi.org/10.2307/1926720

Kvedaras, V. (2005). Explanation of economic growth differences in the CEE countries: Importance of the BOP constraint Baltic. Journal of Economics, 48-65.

Lee, J., \& Mark, C. S. (2003). Minimumlagrange multiplier unit root test with structural breaks. The Review of Economics and Statistics, 85(4), 1082-1089.

León-Ledesma, M. (1999). An application of Thirlwall's law to the Spanish economy. Journal of Post Keynesian Economics.

López, J., \& Cruz, A. (2000). Thirlwall's Law and beyond: the Latin America experience. Journal of Post Keynesian Economics, 22(3).

López-Pacheco, P., \& Thirlwall, A. P. (2006). Trade liberalization, the income elasticity of demand for imports, and growth in Latin America. Journal of Post Keynesian Economics, 29(1), 41-66. http://dx.doi.org/10.2753/PKE0160-3477290103 
McCombie, J. S. L. (1989). Thirlwall's Law and balance of payments constrained growth-A comment on the debate. Appiled Economics, 21(5), 611-629. http://dx.doi.org/10.1080/758524894

McCombie, J. S. L. (1997). On the empirics of balance-of-payments constrained growth. Journal of Post Keynesian Economics, 19(3), 345-375.

McCombie, J. S. L., \& Thirlwall, A. P. (2004). Essays on balance of payments constrained growth theory and evidence. London: Routledge.

McGregor, P. G., \& Swales, J. K. (1985). Professor Thirlwall and balance of payments constrained growth. Applied Economics, 17(1), 17-32. http://dx.doi.org/10.1080/00036848500000002

Moreno-Brid, J. C. (2003). Capital flowsinterest payments and balance of payments constained growth model: a theoretical and empricial analysis. Metroeconomica, 54(2\&3), 346-365. http://dx.doi.org/10.1111/1467-999X.00170

Moreno-Brid, J. C., \& Pérez, E. (1999). Balance of payments constrained growth in Central America: 1950-96. Journal of Post Keynesian Economics.

Perraton, J. (2003). Balance of payments constrained growth and developing countries: An examination of Thirlwall's Hypothesis. International Review of Applied Economics, 17, 1-22. http://dx.doi.org/10.1080/713673169

Perraton, J., \& Turner, P. (1999). Estimates of industrial country export and import demand functions: Implications for Thirlwall's law. Applied Economic Letters, 6(11), 723-727. http://dx.doi.org/10.1080/135048599352295

Pesaran, H., Shin, Y., \& Smith, R. (2001). Bound testing approaches to the analysis of level Relationships. Journal of Applied Econometrics, 16, 289-326. http://dx.doi.org/10.1002/jae.616

Samimi, A., Nouri, R., \& Hosseinzadeh, R. (2011). Foreign trade and economic growth: Evidence of Thirlwall's Law in Iran. Journal of Social and Development Sciences, 2(2), 81-88.

Thirlwall, A. P. (1979). The balance of payments constraint as an explanation of international growth rate differences. Banca Nazionale del Lavoro Quarterly Review, 128, 44-53.

Thirlwall, A. P. (1997). Reflections on the concept of balance-of-payments-constrained growth. Journal of Post Keynesian Economics, 19(3), 377-385.

Thirlwall, A. P. (2011). Balance of payments constrained growth models: History and overview. University of Kent School of Economics Discussion Papers, KDPE 1111, May.

Thirwall, A. P., \& Nureldin, H. M. (1982). The balance of payments constraint, capital flows and growth rate differences between developing countries. Oxford Economic Papers, 34, 498-510.

Yongbok, J. (2009). Balance of payments constrained growth: The Case of China 1979-2002. International review of Applied Economics, 23(2), 135-146. http://dx.doi.org/10.1080/02692170802700476

\section{Copyrights}

Copyright for this article is retained by the author(s), with first publication rights granted to the journal.

This is an open-access article distributed under the terms and conditions of the Creative Commons Attribution license (http://creativecommons.org/licenses/by/3.0/). 